\title{
Hydrological Studies in India During Last Decade: A Review
}

\author{
TANVI ARORA and V M TIWARI*
}

CSIR-National Geophysical Research Institute, Uppal Road, Hyderabad 500 007, India

(Received on 14 June 2018; Accepted on 15 December 2018)

\begin{abstract}
In the recent past, with the availability of enormous datasets and advanced computational skills, hydrological science is trending towards integration of multidimensional studies for the comprehension of complete hydrological cycle. Numerous studies have been carried out in varied hydrological, climatic and geological settings of India during the last decade. These studies cover groundwater exploration and management; surface water-groundwater interactions; geogenic and anthropogenic contaminations; water balances;predictive modelling and others. This article provides a glimpse of these studies. Some reports and studies might not have been described here due to their unavailability in the public domain and due to space limitation.
\end{abstract}

Keywords: Hydrological; Multidimensional Studies; Computational Skills; Anthropogenic Contaminations

\section{Introduction}

India has a great hydrological and climatic diversity; from alluvial plains to hard rock aquifers and Thar Desert, Rajasthan having rainfall less than $250 \mathrm{~mm} /$ yr to Mawsynram, Meghalaya recording 11,872 mm/ yr. These diversities, along with uneven demand of water, are posing a challenge for management of water resources in India. India is bestowed with a large amount of annual rainfall and total average annual river flow is $1953 \mathrm{~km}^{3}$ while the annual utilizable surface water is estimated to be around 690 $\mathrm{km}^{3}$ (Kumar et al., 2005). The total annual replenishable groundwater resources and the net annual groundwater availability as on March 2011 of the country have been assessed to be $433 \mathrm{~km}^{3}$ and $398 \mathrm{~km}^{3}$ respectively while the annual groundwater draft for all uses is $245 \mathrm{~km}^{3}$ (CGWB, 2014-2015). Aquifers in India are broadly categorised as consolidated and unconsolidated formations (Fig. 1). The water resources of India and other related information are summarized in Table 1. Almost $83 \%$ of the water resources are being used in the agriculture sector and the rest are utilized for domestic, industrial and other activities (Table 2). The distribution of groundwater in the country is highly diverse and the availability of safe drinking water from many aquifers is restricted due to geogenic contaminants. Considerable decline of well yields and the depletion of groundwater levels are the major concerns. The situation is further worsened due to the water contamination, and extreme conditions of climate variability including floods and droughts. Extreme climatic events pose more challenges to groundwater management plans. The various geo-spatial datasets related to hydrology (including topography, Land Use Land Cover (LULC), soil etc) are available through open sources like Bhuvan (http://bhuvan.nrsc.gov.in) and India-Water Resources Information System (India-WRIS, http://www.india-wris.nrsc.gov.in/) which are routinely used for governance, administrative purpose as well as research in hydrological sciences.

\section{Surface Water Resources}

Surface water hydrology includes water availability analysis, flow duration curve analysis and environmental flow requirement, flood estimation and routing, structural and non-structural measures of flood management, snow and glacier melt monitoring and modeling, sedimentation studies for flood control etc.

*Author for Correspondence: E-mail: virendra.m.tiwari@gmail.com 


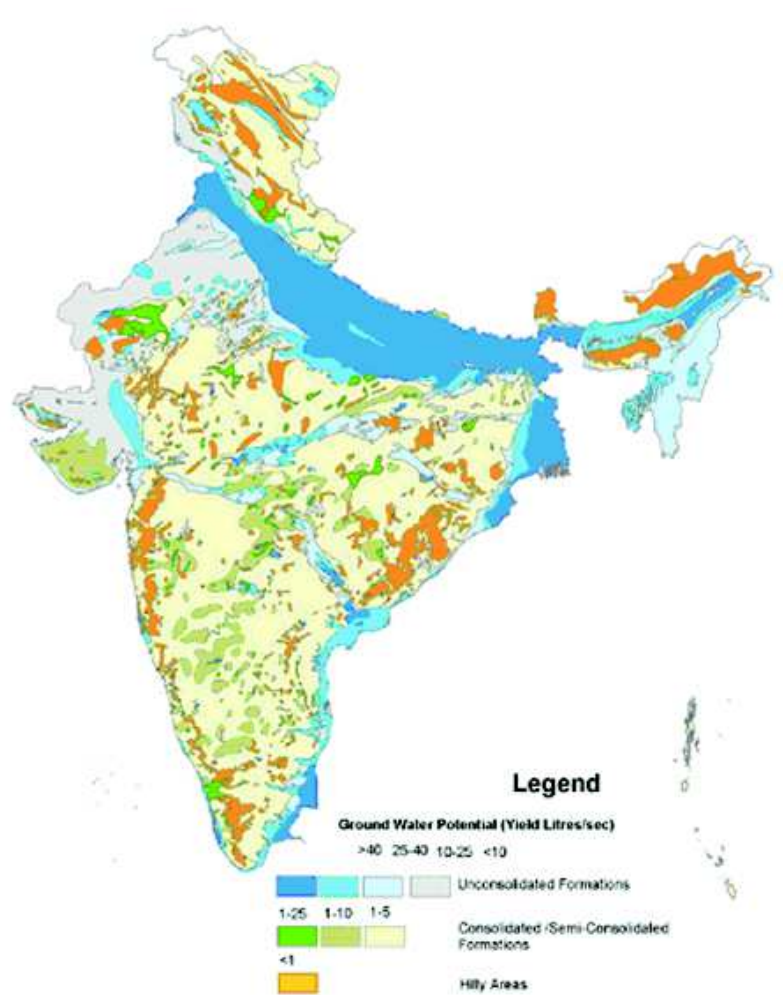

Fig. 1: Map showing the hydrogeological map of India with different formations. (Source: https://india-wris.nrsc. gov.in/)

Almost $61.5 \%$ of utilizable water available within country belongs to the surface water resources.

Glaciers and snow cover play a pivotal role in controlling the headwater river run-off variability of monsoon influenced areas (Thayyen et al., 2007). A positive regional mass balance as well as reduction of river runoff for the period 1999 to 2008 is reported from the Hindu-Kush-Karakoram-Himalaya glaciers and it is suggested that the contribution of Karakoram glaciers to sea-level rise is- $0.01 \mathrm{~mm} / \mathrm{yr}$ (Gardelle et al., 2012). A consistent and prolonged negative mass balance in Western Himalaya from 1997 to 2014 is ascribed to the increased supraglacial debris cover (Pratibha et al., 2018). It is proposed that this approach of finding debris cover can be adopted to study the effect of climate change with respect to mass balance and increase in the number of supraglacial and moraine dammed lakes on much larger spatial scale in different regions of Himalaya.Glacier-mass balance approach was adopted to infer the high-altitude precipitation in the upper Indus Basin and it was shown that the amount of precipitation required to sustain the observed mass balance of large glacier systems is far beyond that at valley stations or estimated by gridded precipitation products (Immerzeel et al., 2015). The findings from this study had an important bearing on climate change impact studies, planning and design of hydropower plants and irrigation reservoirs. Haritashya et al. 2010 made a detailed study of the temporal variations in particle size, texture, mineralogy, origin and evacuation pattern of the sediments based on studies on the proglacial meltwater stream of Gangotri glacier for the period 2000-2006. A study related to climatic processes and their genesis is carried out in middle Satluj Valley, western Himalaya (Sharma et al., 2017). Pottakkal et al. (2014) attempted dye tracer experiments to characterize the subglacial pathways that transport the meltwaters from glaciers through the lower ablation zone of the Gangotri glacier.The studies mentioned that the actual snowmelt contribution remains speculative under both present and future climatic conditions (Siderius et al., 2013).

A regression model for runoff forecasting is developed using available hydro-meteorological data within a glacial valley (Srivastava et al., 2014). Twenty-five flood events are correlated with sediments which were generated and transported from higher Himalayan crystalline and the trans-Himalaya regions. These events were supposed to be generated by landslide lake outburst floods during precipitation. The coupling between the moisture bearing monsoon circulation and southward penetrating mid-latitude westerly troughs were implied for extreme precipitation events and such outburst floods.

Most of the Indian river basins are climate sensitive and the study of their sediments provides a better understanding of continental-scale fluvial system, variations in weathering and erosional processes over the whole subcontinent. The river Ganga, originating from Himalaya, is the most dynamic among world's major rivers. The sediments of the Ganga river were analyzed for its textural properties (characterized by fine to very fine sand at Himalaya orgenic belt; medium to find sand at northern Indian craton and very fine sand to clay at alluvial plain region), grainsize characteristics (nearly $80 \%$ of bedload sediment to be transported as graded suspension) and transportation dynamics (extremely 
Table 1: Water resources of India (Source: Central Water Commission)

\begin{tabular}{|c|c|c|}
\hline S.No. & Description & Value \\
\hline 1 & Geographical area \& location & $\begin{array}{l}\text { 328.7 M ha Latitude } 8^{0} 4^{\prime} \& 37^{0} 6^{\prime} \text { North Longitude } \\
68^{\circ} 7^{\prime} \& 97^{0} 25^{\prime} \text { East }\end{array}$ \\
\hline 2 & Population as of 2011 & 1210.19 Million \\
\hline 3 & Rainfall variation & $\begin{array}{l}\sim 100 \mathrm{~mm} \text { in Western most regions to } \sim 11000 \mathrm{~mm} \text { in } \\
\text { Eastern most regions }\end{array}$ \\
\hline 4 & Major river basins (catchment area $>20,000 \mathrm{Sq} \mathrm{km}$ ) & 12 Nos. Having a catchment area $253 \mathrm{M}$ ha \\
\hline 5 & Medium river basins (catchment area between 2000 and 20,000 Sq km) & 46 Nos. Having catchment area $25 \mathrm{M}$ ha \\
\hline 6 & Average annual rainfall (2010) & 3989 BCM \\
\hline 7 & Mean annual natural run-off & $1869 \mathrm{BCM}$ \\
\hline 8 & Estimated utilisable surface water potential & $690 \mathrm{BCM}$ \\
\hline 9 & Total replenishable groundwater & $431 \mathrm{BCM}$ \\
\hline 10 & Groundwater resources available for irrigation & $369 \mathrm{BCM}$ \\
\hline 11 & $\begin{array}{l}\text { Groundwater potential available for domestic, industrial and other } \\
\text { purposes }\end{array}$ & $\sim 71 \mathrm{BCM}$ \\
\hline 12 & Maximum irrigation potential & $140 \mathrm{M}$ ha \\
\hline 13 & Irrigation potential from surface water & $76 \mathrm{M}$ ha \\
\hline 14 & Irrigation potential from groundwater & $64 \mathrm{M}$ ha \\
\hline 15 & $\begin{array}{l}\text { Storage available due to completed major \& medium projects } \\
\text { (including live capacity less than } 10 \mathrm{M} \text {. cum) }\end{array}$ & $253 \mathrm{BCM}$ \\
\hline 16 & Total cultivable land & $182.2 \mathrm{M}$ ha \\
\hline 17 & Gross sown area & 192.2 $\mathrm{M}$ ha \\
\hline 18 & Net sown area & $140.0 \mathrm{M}$ ha \\
\hline 19 & Gross irrigated area & $86.4 \mathrm{M}$ ha \\
\hline 20 & Net irrigated area & $63.3 \mathrm{M}$ ha \\
\hline 21 & Ultimate hydropower potential (as per reassessment) & $84044 \mathrm{MW}$ at $60 \%$ L.F. \\
\hline 22 & Potential developed by $31^{\text {st }}$ March, 2014 (installed capacity) & 40531.41 MW \\
\hline
\end{tabular}

Table 2: Water use in India

\begin{tabular}{ll}
\hline Sectors & Consumption of water \\
\hline Agriculture & $83 \%$ \\
Domestic & $7 \%$ \\
Industry & $2 \%$ \\
Energy $1 \%$ & \\
Other $7 \%$ & \\
\hline
\end{tabular}

high rate of water discharge, huge sediment load during monsoons and high discharge variability) by Singh et al. (2007).

The effective discharge for suspended sediment transport in the alluvial reaches of Ganga River in the Western Ganga Plains was computed using analytical and an alternative magnitude-frequency approach. It was concluded that the effective discharges at different places have recurrence interval of 1-2 years and are channel maintaining (Roy et al., 2014). It was proposed that the changes in the effective discharge (monsoonal fluctuations) influenced the long-term landscape development and valley filling episodes in the Ganga river plain.Hydrology and sediment dynamics were linked to landscape diversity in the Ganga dispersal system (Roy et al., 2017).

Mahi River basin in western India, was quantified for contemporary and paleo-discharges and the changes in the hydrologic regime through midlate Holocene. In this river basin the discharge estimates were based on the channel dimensions and established empirical relations for mid-late Holocene, 
historic and the present ones. It was inferred that the precipitation is showing a decreasing trend since the mid-late Holocene (Sridhar, 2007). Important hydrological features of the flood region were investigated to treat entire Damodar river system from source to mouth. The climatological data along with stream flow records were analysed. The study revealed the significant changes in the hydrological behavior of the region were characterized by an increase in temperature levels and reduction in rainfall and river flows (Roy and Majumdar, 2007).

A few other characteristics of surface water resources were made available by other workers. The implications of forest use and reforestation on surface and sub-surface hydrology were explained by Bonell et al., 2010. The importance of soil water retention capacity to maintain the base flow levels and the effect of deforestation was conveyed by Qazi et al., 2017. An integrated approach using remote sensing data, borehole data, field data, isotopic and water level data was adopted to identify major paleochannels and studied their hydraulic connectivity with adjacent alluvial plains, rate and source of natural recharge and the groundwater flow direction (Samadder et al., 2011).

\section{Groundwater Resources and Aquifer Mapping}

The conventional electrical method (Vertical Electrical Soundings) continues to be the most reliable method for correlating the geoelectrical parameters with lithology to delineate groundwater potential zones. Such studies are carried out in the Tamil Nadu (Ballukaray, 2001) and other parts of the country. A number of researchers have successfully carried out groundwater exploration and modeling to assist in sustainable long-term management of groundwater resources (Mondal and Singh, 2004; Saxena et al., 2005; Mondal et al., 2011). Use of Electrical Resistivity Tomography (ERT) resolved various challenging problems faced by the Geoscientists working with geohydrological and geotechnical methods (Andrade, 2011). Among the other geophysical methods, Mise-le-masse technique to locate the extension of fractures in hard rocks (Kumar et al., 2003), use of gravity methods in crystalline aquifers (Murty et al., 2002), seismic methods for delineation of aquifers (Sundararajan et al., 2004) and integrated studies using hydrogeology (Singh et al.,
2003, Dutta et al., 2006, Barker et al., 2003, Sharma et al., 2005, Rai B, et al., 2005, Hodlur et al., 2006, Dar et al., 2017) are successfully employed for groundwater studies. Over the decade, a systematic approach towards mapping of aquifer and groundwater management techniques led to initiation and accomplishment of an ambitious programme of pilot aquifer mapping over the six representative terrains of the country (Ahmed, 2014). An area of approximately $3,264 \mathrm{~km}^{2}$ covering Deccan Traps of Maharashtra, desert areas of Rajasthan, Gangetic plains of Bihar, coastal region of Tamil Nadu, contaminated aquifer system of Bihar and hard rock aquifers of Karnataka and Rajasthan were explored. The dual-moment Aero-Electromagnetic methods were effective in delineating the $3 \mathrm{D}$ aquifer configurations marking a new chapter in the hydrological science in India. The Heliborne Transient Electromagnetic surveys were used to delineate the aquifer geometry and identify the conductivity patterns in a few chosen areas of hard and soft rock aquifers in the pilot aquifer mapping. These results were used to validate and model the hydrogeology of an area in Rajasthan (Chatterjee et al., 2018).

Remote sensing techniques were applied to assess groundwater favorable zones for development and exploration in and around Guntur area in Andhra Pradesh. It was observed that the deeply weathered pediplain (PPD), moderately weathered pediplain (PPM) and shallow weathered pediplain (PPS) are good, moderate to good and poor to moderate groundwater prospect landform whereas residual hill (RH) was considered as a poor groundwater prospective zone (Subbarao et al., 2001). Further satellite imageries were used to explore the groundwater potential zones and identifying sites for rainwater harvesting sites in Aravalli-Pegmatite Precambrian terrain of Delhi (Mukherjee, 2008). Groundwater flows were delineated by observing the impact of water table variations and depth-dependent fracture connectivity (Guiheneuf et al., 2014). A plan of artificial recharge to groundwater in 22 States/UT of India has been efficaciously implemented by the Ministry of Water Resources (Annual Report, CGWB, 2016, www.cgwb.gov.in).

\section{Prediction and Modelling}

Monsoon rainfall is a major source of water in India. Indian Meteorological Department (IMD) is the nodal 
government agency, which issues seasonal prediction (LRF) based on a statistical forecast system with 8 predictors, which have a strong physical linkage with Indian summer monsoon. Statistical models have their own limitations due to their dependence on interrelationship of predictors (Rajeevan et al., 2008) and therefore, ensemble mean forecast (with an assumption of prediction between 7-45 days) is often adopted Forecast model is improved using bias correction for precipitation and air temperature (Shah et al., 2017). Pattanaik and Kumar (2010) showed that even though the major features of monsoon are predicted successfully in all forecasts between March and May, the significant correlation of ISMR with observations are noticed for forecasts initiated in April only. Ramu et al. (2016) attributed the skill of ISMR to the better teleconnections of El Nino related SST and ISMR in these models and in a recent publication, Ramu et al., (2017) came out with a dynamic prediction system for seasonal summer monsoon rainfall over five homogenous regions of India by showing a higher anomaly correlation coefficient (ACC-0.45). A case study on the semi-arid Musi subbasin $\left(11,000 \mathrm{Km}^{2}\right)$ of Krishna Basin was performed using three dimensional MODFLOW model (Massuel et al., 2013) and two water allocation scenarios were assessed and compared. Simulations involving all sources and sinks showed that there is $13 \%$ less groundwater available for exploitation as compared to the one modelled on the groundwater availability linked to quantifield fluxes. By integrating complex interactions between components of the water budget in space and time, the groundwater model was able to provide a more comprehensive conceptual assessment of the groundwater-resource sustainability. In turn, this has major implications for the existing water allocation modelling framework used to guide decision makers and water-resources managers worldwide.

Ghosh and Majumdar, (2008) presented a methodology of statistical downscaling based on sparse Bayesian learning and Relevance Vector Machine (RVM) and generated a model at river basin scale for monsoon cycle using General Circulation Model (GCM) simulated climatic variables. To address the problem of handling the dynamic, non-linear and noisy data to understand the physical processes in watershed, Nayak and Sudheer, (2008) came up with a Fuzzy model for reservoir inflow forecasting in the
Narmada basin. In addition, Singh et al. (2008) proposed a new conceptual sediment graph models based on coupling of popular and extensively used methods like Nash model based instantaneous unit sediment graph (IUSG), soil conservation service curve number (SCS-CN) method, and Power tawwhich vary in their complexities. Correspondingly, Dhar and Mazumdar, (2009) came up with a hydrological model of the Kangsabati river, West Bengal, with reference to climate change scenario. Parameters (evapotranspiration, transmission losses, potential evapotranspiration and lateral flow) were evaluated and predicted for years 2041-2050 towards sustainable development of the river basin which show an increasing trend over the time period. Singh et al. (2010) deliberated on the impacts of climate change on discharge of River Irrawaddy in the Loktak Lake watershed, which included a wetland in Northeast India. This was achieved by running pattern-scaled GCM output through distributed hydrological models (developed using MIKE-SHE) of each subcatchment.

In addition to conventional statistical methods, the kernel-based machine learning approaches gained popularity including Artificial Neural Networks (ANNs). Gupta et al. (2011) used the Global Circulation Model (HadCM3) projected data to quantify the impact of climate change on runoff of the lower part of Ganga Basin and upper parts of Mahanadi Basin. Their results predicted a decline in the future climatic runoff in most of the river basins of India as compared to normal climatic runoff further indicating that the agriculture in the eastern India may be more affected due to shortage of surface water availability. Similarly, Islam et al. (2012) assessed the impacts of climate change on streamflow of the Brahmani River basin using Precipitation Runoff Modeling System (PRMS) run under the platform of Modular Modeling System (MMS). In contrast to this, Goyal et al. (2012) worked on downscaling of the output of GCM to obtain simultaneous projection of mean monthly maximum and minimum temperatures (T-max and T-min) along with monthly precipitation and pan evaporation to lake-basin scale in climatically sensitive semiarid region of India. They used the nonparametric methodofK-Nearest Neighbor (K-NN) approach to select the nearest neighbors for projections. Model predictions associated with different climate change and abstraction scenarios in 
the Upper Bhima Basin indicated that the continuation of current rates of abstraction would lead to significant groundwater overdraft, with groundwater levels predicted to fall by $-6 \mathrm{~m}$ in the next 3 decades (Surinaidu et al., 2013); Physically-Based Distributed (PBD) hydrological model, the Distributed Runoff and Erosion Assessment Model (DREAM) predicted sediment flow rates and sediment yields in Pathri Rao watershed in Garhwal Himalayas (Ramsankaran, 2013). The hydrological impacts of climate change in Central Indian River basin were studied by Raje et al. (2014) using Variable Infiltration Capacity (VIC) MHM (macroscale hydrologic model). This studyshowed an increasing trend for summer monsoon surface runoff, evapotranspiration and soil moisture in most of the central Indian river basins. On the other hand, a decrease in runoff and soil moisture are projected for a number of regions in southern India, with important differences arising from GCM and scenario variability using VIC model over Ashti catchment (Godavari Basin) to evaluate the impacts of LULC changes and rainfall trends on the hydrological variables (Hengade et al., 2016). The hydrologic impacts of climate change in Tunga-Bhadra river basin, India were assessed using HEC-HMS and SDSM models, by comparing present and future stream flow and evapotranspiration estimates (Meenu et al., 2013); Modelling hydrology, groundwater recharge and non-point nitrate loadings were carried out in the Himalayan Upper Yamuna basin by integrating hydrological SWAT model with the MODular finite difference groundwater FLOW model (MODFLOW) and Modular 3-Dimensional Multi-Species Transport model (MT3DMS) (Narula and Gosain, 2013). It also includes studies on rainfall (Menon et al., 2013; Salvi and Ghosh, 2013etc.), water availability and streamflow (Gosain et al., 2011; Singh and Kumar, 2015), soil erosion (Mondal et al., 2014), water quality (Rehana and Mujumdar, 2012), irrigation demands (Rehana and Mujumdar, 2013), and groundwater availability and recharge (Panwar and Chakrapani, 2013).Also, the advances in computational techniques for the enhanced hydrological modelling in the Indian context were reviewed and discussed by Mondal et al., 2016.

Numerical Weather Prediction model output was used to verify the spatio-temporal monsoon rainfall variability across theIndian region. It was observed that the prediction of dry spell rainfall was more uncertain than that of the wet spell. The percentage area of India under wet conditions (rainfall amount over each grid is more than its daily mean monsoon rainfall) and rainwater over the wetarea is overestimated by about $59 \%$ and $32 \%$, respectively, in all models (Ranade et al., 2014).

The reliability of hydrological models for prediction in ungauged basins (PUB) was improved. The potential of multi-basin modelling for comparative hydrology using PUB grouped 6000 sub-basins on the basis of similar flow signatures. This gave more insights into the spatial patterns of flow generating process at larger scale (Pechlivanidis and Arheimer, 2015). This hydrological setup was named as India-HYPE (Hydrological Predictions for the Environment).

Tiwari et al. (2018) examined the mid-21 ${ }^{\text {st }}$ century climate projections over western Himalaya from Coupled Model Intercomparison Project Phase 5 (CMIP5) global climate models under Representative Concentration Pathways (RCP) scenarios (RCP4.5 and RCP8.5). It was proclaimed that the western Himalaya and Satluj River Basin will be warmer by mid-century. Considering the reported models with different assumptions, Chawla and Mujumdar (2018) provided a generalized framework for hydrologists to examine stationarity assumption of models before considering them for future streamflow projections and thereby isolate the contribution of various sources to the uncertainty.

\section{Changing Scenarios with Climate Variability}

\section{Climate Dynamics}

Impact of the climate change on the water resources of Indian river system using the HadRM2 daily weather data to determine the spatio-temporal water availability in the river systems was quantified (Gosain et al., 2010). In this study, SWAT was used to prepare the distributed hydrological model. Simulations over 12 river basins were made, using the data for over 40 years (20 years for Present and 20 years for Green House Gas or future climate scenario), which revealed that two out of 12 river basins are predicted to be the worst affected (one with respect to floods and other with respect to the droughts). Similar impact study for Bhavanisagar Reservoir of Tamil Nadu was attempted by Wilk and Hughes, (2002). They simulated the impact of land-use and climate change 
on water resource availability for Bhavanisagar Reservoir of Tamil Nadu and concluded that the landuse and climatic changes that are likely to occur (apart from extreme events) will have a negligible impact on the yield of the Bhavanisagar Reservoir.

In regional and global modelling studies for climate change assessments, Sen Royet al. (2007) supported the use of irrigation and agricultural impacts along with land use change and aerosol feedbacks. In their work, they analysed the monthly climatological surface data sets at the regional level over India and showed that agriculture and irrigation can substantially reduce the air temperature over different regions during the growing season. The macro scale study over the tropical site in Gujarat also indicated that the absorbing aerosols delay the growth and promote the early collapse of atmospheric boundary layer (Pandithurai et al., 2008).

The climate change impact on hydrology and water resources was assessed by Majumdar (2008) along with the variability in sustainable water resources planning and management. Further, the role of clouds in affecting the sub-season/intra-seasonal variability of sea surface temperature (SST) and atmospheric convection in the equatorial and SouthEastern Tropical Indian Ocean (SETIO) during monsoon break transitions were analysed by Samala and Krishnan (2008).

The first basin-wide assessment of the potential impact of climate change on the hydrology and production of the Ganges system was presented by Jeuland et al. (2013) as a part of the world Bank's Ganges Strategic Basin Assessment Program. Based on the series of modelling efforts (including downscaling of climate projections, water balance calculation, hydrological simulation, economic optimization), the General Circulation Models (GCC) were found to be highly variable. This leads to considerable differences in predictions of means flows in the Ganges and its tributaries.

It was submitted that the unsteady nature of the onset phase of the monsoon and the dependency of its migration on regional hydrological processes makes northwestern India, in particular, susceptible to variability and changes (Bollasina et al., 2013). This study used atmospheric general circulation model in a realistic configuration to conduct "perpetual" experiments aimed at providing new insights into the role of land-atmosphere processes in modulating the annual cycle of precipitation over India.

The variations in rainfall indices found to be driven by large scale climate variability in a study of extreme rainfall indices over 57 urban areas of India during the period (1901-2010) gave a future projection of climate for next 50 years upto 2060 (Ali et al., 2014). It was shown that the urban areas with major increase in rainfall maxima under the projected future climate is far larger than the number of areas that experience significant changes in the climate during the $20^{\text {th }}$ century. These results indicated a strong need for urban storm water infrastructure planning and management arising out of climate dynamics. The decrease in the intensities of Indian Winter Monsoon (IWM) and its response to external forcing over the last 250 years were suggested (Munz et al., 2017) as a part of climate variability.

\section{Contamination of Hydrological Resources}

The groundwater pollution studies routinely carried out by Central Pollution Control Board (CPCB) reported high level of arsenic, fluoride and other industrial hazardous wastes during the last decade. The national compilation of all the relevant information on major geogenic contaminants in and their remediation for major parameters like arsenic fluoride, salinity, iron and manganese, uranium, radon, strontium, selenium and chromium are compiled and reported with special emphasis on Nitrate (CGWB, Annual report, 2014). Geogenic contamination studies in the principal aquifers of local areas of Yavamal Maharastra. The defloridation units were installed at the community level and improvement in the health was indicated (Gwala et al., 2014).

Arsenic contamination produced from shallow depths in the parts of Damodar fan-delta and west of Bhagirathi river in West Bengal and Bengal basin were reported by many workers. The deep domestic pumping only slightly perturbs the deep groundwater flow system while the substantial shallow pumping for irrigation forms a hydraulic barrier that protects deeper resources from shallow arsenic sources. Michael et al.,(2008), evaluated the sustainability of deep groundwater as an arsenic-safe resource in the Bengal basin. Coyte et al. (2018) demonstrated the enhancement of Uranium mobilization from geogenic 
cause to anthropogenic cause. They further stressed the need to revise the current water quality monitoring program in India, measures of evaluation of human health risks in high uranium prevalent areas, improvement of remediation technologies and proper implementation of preventive management practices to solve the problem.

The understanding of hydrochemical parameters and activity of natural radionuclides ( $\mathrm{H}-3)$ was used to determine the relative age of groundwater in the river basins of Karnataka (Ravi Kumar et al., 2011). On this basis, the agricultural water management (AWM) strategy was adapted with an aim to increase the agricultural production through the enhancement of available water resources while maintaining ecosystem services (Garg et al., 2013). In addition, improvement in the ability to develop Environmental flows assessment (EFA) through difference case studies from rivers across the country resulted in developing sustainable management of the water system (Jain and Kumar, 2014). The major focus for the development of EFA was to create an open database for hydrological, ecological and socioeconomic data, developing hydrology-ecology relationships, evaluation of ecosystem services, and addressing pollution due to anthropogenic activities. The studies on the chromium dumpsites indicated that the leaching of carcinogenic hexavalent chromium from COPR dumpsites leading to groundwater contamination is a major risk to environment (Matern et al., 2017). Renganayaki et al. (2013) developed a concept of inverting the water quality as an effectof recharge to address the geogenic and anthropogenic contaminations.

Participation in international projects supported integrated treatment process for agro-food industry effluents and the municipal wastewater (Annual Report, NEERI, 2012). The concept of "zero emission" and "zero discharge" was also started providing Environmental Impact Assessment (EIA) certifications to different industries which is a landmark achievement.

\section{Origin and Source of Floods in India (Palaeo- flood-Hydrology)}

Annual flooding of monsoon-fed rivers are caused due to high spatio-temporal variability of rainfall. Paleoflood hydrology, which studies the recent and historic records of large floods is an upcoming field of hydrology. The potential of palaeoflood hydrological studies in the Indian context was highlighted by summarising the results for eight Indian rivers over the last two decades and it concluded that such studies in different hydro-geomorphic regions of India are vital for flood-risk assessment of gauged as well as ungauged rivers (Kale 2008). The study proposed that the potential for palaeoflood analysis was high in Deccan rivers, dominated by favourable lithologies (granite, gneisses, sandstones and quartzites) along with stable boundary conditions. Contrary to this, the potential for palaeoflood studies was low in alluvial rivers particularly in Ganga-Brahmaputra Plains and Gujarat Plains. The study revealed that the potential for reconstructing past or recent natural dam-failure during floods was high in Himalayan rivers. It was clearly pointed out that the real data on extreme climatic events produced by palaeoflood records may help in modelling and predicting the future climate changes. Baker (2008) included new techniques for accurate geochronology of flood sediments to solve the coupled hydraulic calculations.

The fluctuations of the monsoon over the Indian sub-continent, paleo-hydrological changes of two playas, Phulera and Pokharan, in Thar desert were studied by Roy et al. (2009) using stratigraphical, mineralogical, geochemical and optical dating methods. They concluded that the sediment successions in shallow profiles from these two playas contain three and four stratigraphic units along with characteristic geochemical properties. Sridhar (2009) showed an evidence of correlation between the extreme hydrological events in Mahi, Narmada and Tapi river basins and attributed them to the regional monsoon domain. He stressed that the palaeoflood records are of great significance in revealing the magnitude and frequency of large floods.

\section{Challenges Along the Coast (Coastal Hydrology)}

The Indian coast line hosts 77 major cities with different challenges such as lack of drainage system, overdraft of groundwater, sea water ingression and variations in agricultural practices while the deltaic plains have their own challenges.

A number of studies were carried out to address the problems arising out of irregular withdrawal leading to saltwater intrusion. A simulation model 
based on groundwater quality in the Godavari delta developed by Ghosh (2002) indicates a considerable increase in seawater intrusion. Upstream development and inter-annual variations in rainfall of Indian river basins is likely to cause both episodic (periodic) and chronic (constant) shortages in water supplies downstream. Rapid development of surface and groundwater throughout thebasin in India resulted in historically low inflows to the main canals. The situation in these deltas is much worse as widespread seawater intrusion is transforming the fresh groundwater to brackish/saline water (Saxena et al., 2004) even in the channel islands like Pesarlanka (Mondal et al., 2010).

A flow and transport simulation model, on the basis of finite element method, was established to evaluate the effectiveness of planned strategies for pumping, in order to locally control the intrusion (Datta et al., 2009). Submarine groundwater discharge (SGD) with special reference to its prevalence as a source of freshwater and nutrients to coastal ecosystems is prominent in coastal research. Very recent study carried out by National Centre for Earth Science Studies (NCESS, annual report 2016) on geomorphological mapping and submarine groundwater discharge reported the lithology variations, water table fluctuations and hydrochemical heterogeneity along the coastal aquifers of Kozhikode in a scientific manner. Kanagaraj et al., (2018) investigated the influence of seawater intrusion in the coastal aquifers of Kalpakkam, Kancheepuram district of Tamil Nadu by using integrated geophysics, geochemical and stable isotopes techniques and recommended various precautions to be adopted. Central water Commission (CWC) recently examined the salination issues of surface to coast with solution specific study (CWC salinity report 2017).

\section{Use of Isotope for Subsurface Studies (Isotope and Tracer Hydrology)}

The source of wetland groundwater, surface watergroundwater interaction and mixing of groundwater at different depths of aquifer was understood (Sikdar and Sahu, 2009) using isotopic signatures associated with hydrogeology of East Calcutta Wetlands, a periurban inland wetland ecosystem. They utilized hydrogeology and isotope composition of groundwater to understand the present hydrological processes prevalent in the wetland, source of wetland groundwater, surface water-groundwater interaction and mixing of groundwater of various depth zones in the aquifer. Their study concluded that the shallow groundwater has high tritium content due to local recharge whereas the deep groundwater has low tritium due to recharge at distant area. At some places, high tritium in deep aquifer was attributed to mixing of groundwater from both shallow and deep aquifers. Isotopic signatures and geochemical behaviour of groundwater in an arsenic-enriched part of the Ganga Plain helped in characterizing the recharge processes in both the shallow and deeper aquifers (Saha et al., 2011). In the reservoir triggered seismicity area of Koyna-Warna region, a model was conceptualized based on the hydrochemical and isotopic characteristics of different well waters for aquifer breaching and mixing of deep aquifer water with shallow aquifer water due to earthquakes (Reddy et al., 2011).

The stable isotope delta O-18 was used to identify stream and spring origins of a mountainous catchment in a case study from Liddar watershed, Western Himalaya, India (Jeelani et al., 2010). The spatial and temporal distribution of delta O-18 and delta D measurements in precipitation and stream waters were used to distinguish various sources and components of stream flow and to estimate their residence times in snow dominated mountainous catchments of Kashmir Himalaya (Jeelani et al., 2013). Air-mass trajectory analysis to find out the moisture contribution of rains over the Kolkata city indicated that these moisture traces originate from Arabian Sea and travel over dry continental region over the Bay of Bengal before arriving Kolkata (Dar et al., 2017). The same isotope (delta $\mathrm{D}$ and delta O18) along with strontium was used in Indus River water to understand the regional hydrology, water sources, and catchment processes (evaporation, transpiration, recycling and mixing) by Sharma et al. (2017). Isotopic studies in Indus civilization of northwest Rajasthan provided an evidence for the climate change in this region associated with both expansion and contraction of Indus urbanism along the desert (Dixit et al., 2018).

Department of Science and Technology, GOI and Physical Research Laboratory (PRL) funded a programme on Isotopes led by Deshpande and Gupta (2007) under the title "National Program on Isotope 
Fingerprinting of Waters of India (IWIN) - a New Initiative". The major objectives of the program included generation of isotope data for addressing important hydrological questions related to origin of water sources and the processes of redistribution by evapo-transpiration, stream flow generation, groundwater recharge and discharge - from watershed to continental scale; and providing quantitative estimates of residence time of the water and vapour in each hydrological reservoir and the fluxes across them in a temporally and spatially distributed manner.

\section{Applications of Big Dataset from Satellite Observations}

Information from big datasets is well presented by applying remote sensing methods and thematic maps. With the latest data acquisition systems, it is now possible to obtain many conclusive results for recharge structure sites, water balance studies, agro-hydrology balance studies, forecasting or predictive studies, basin assessment studies, etc. National Remote Sensing Corporation (NRSC) has been playing a vital role in mapping the resources through satellite images to be used for agriculture planning, atmosphere and climate, water resources and many more. Their major focus is on irrigation infrastructure monitoring and performance assessment, water bodies monitoring, basin level water resources assessment, flood forecasting and inundation modelling studies, reservoir capacity loss assessment, preparation of nationwide Ground Water Prospect (GWP) maps at 1:50,000 scales etc. Their output is beneficial in providing baseline information studies for decision support for effective planning, monitoring and management of water resources so as to prepare frameworks for water resource models. The delineation of water bodies using SAT-1/SAT-2 A WiFS/LISS-III data is useful for mathematical assessment of the data characteristics along the glaciers as well as morainedammed lakes. NRSC works closely with CWC in providing exclusive datasets for proper planning. Their involvement in Accelerated Irrigation Benefit Programme (AIBP) helped CWC in proper management of canals as well as irrigation network.

On the basis of the confluence dynamics of the Ganga-Ramganga Valley, detailed analysis of the channel morphology, hydrology and sediment transport characteristics of the different rivers was studied through mapping of channel configuration using multidate remote sensing images and topographic sheets for 90 years (1911-2000) by Roy and Sinha (2007). Sinha et al. (2008) integrated the hydrological analysis with GIS based floor risk map in Kosi river basin and reported very high discharge variability and high sediment flux from an uplifting hinterland. Sreedevi et al. (2013) showed the efficacy of SRTM DEM and GIS based approach in evaluating drainage morphometric parameters over the conventional methods. Meraj et al. (2015) used Linear Imaging Self-Scanner satellite data and Advanced Spaceborne Thermal Emission and Reflection Radiometer digital elevation model in a GIS environment for assessing the surface hydrological behavior of Lidder and Rembiara watersheds of the Jhelum basin which helped in formulating better flood mitigation strategies in this data scarce part of the Himalayan region. Garg et al. (2017) investigated the capabilities of variable infiltration capacity hydrological model to hydrologically simulate the Pennar basin under LULC scenarios. Chaudhuri et al., (2017) showed that the remote sensing based estimates of impervious surface area in urban hydrology are very important indicators for the assessment of water resource depletion. They also developed a correlation between land-use change and their potential impact on urban hydrology. Sentinel1 and Sentinel-2 data were used to estimate the seasonal impact of groundwater use in the granitic watershed in South India (Ferrant et al., 2017). Gupta and Singh (2016) discussed the methodology to retrieve the hydro-meterological parameters estimated from satellite based instruments (including Altimeters, Radar, Optical and microwave radiometers) and their variability in case of extreme conditions of drought and flood over India.

CWC came out with a study for "Reassessment of water availability of River Basins in India using Space inputs" for assessing the average annual water resources in the country (2017). The study was approved by Ministry of Water Resources, River Development and Ganga Rejuvenation (MoWR, RD \& GR), Government of India. NRSC developed a tool that integrates all input images like basin boundary, LULC, soil, rainfall, temperature, command area and reservoir mask and generates the outputs in the form of image layers and test files. Various abstractions were estimated for 20 basins/sub-basins of India for 
a 30 year period from 1985-2015. Water resource availability at the basin scale was assessed by model outputs from computed groundwater fluxes using the data from CGWB. This study by CWC laid emphasis on basin scale wealth quantification through transformation from present basin terminal gauge site discharge, aggregation to meteorological data based water budgeting exercise through hydrological modelling approach.

Gravity Recovery and Climate Experiment (GRACE) allow the possibility of measuring the spatio-and-temporal variations in total terrestrial water storage giving precise estimates of water storage over different time scales. The study by Tiwari et al., (2009) stressing the depletion of North Indian aquifers alerted the water managers to take precautionary measures. As per the study, the areas showing decrease in groundwater storage fall in the Ganga River Basin, which is densely populated and also a major contributor of agricultural products. Since then, these aquifers are investigated by various research communities for further estimates (Chen et al., 2014, Long et al., 2016). Very recently, the spatial and seasonal variations of the surface water budget are examined (Singh et al., 2017) by using GRACE measured gravity anomalies on earth to estimate Total Water Storage (TWS) content over the NW region of India.

\section{Critical Zone Studies}

Various processes in the critical zone affect each other directly or indirectly. Integrating these subsurface process is always a challenge due to temporal and spatial variability. Climate change may increase aquifer uses and rates of depletion, thus increasing complexity and challenges of aquifer management. Key climate impacts on aquifers are changes in recharge and discharge zones and volumes, contamination and saline infiltration. Critical zone comprises of the unsaturated zone, all above the water table to the tip of the trees. Unsaturated zone is the most important zone for deciphering the pathways of rainfall recharge as well as the infiltration of contaminants to the aquifer system. This process pertains directly to the climate system as the moisture to the atmosphere is highly dependent on the complexity of a few meters of the sub-surface and is equally important parameter for the long term sustainable monitoring of the aquifers.
Kumar et al. (2009), Anoop et al. (2017) and Pal et al. (2017) used the satellite data to retrieve the soil moisture qualities and their variabilities. CSIR-NGRI designed a different experiment to relate the soil moisture (from neutron probe) and resistivity variations in vadose zone through time lapse geophysical datasets and proved the efficacy of fourth dimension (time) parameter for locating the point of recharge as an input to the model (Arora et al., 2016). Geophysical methods gained importance towards studying the small scale variability of critical zone. However, the relationship between soil moisture and electrical resistivity could not be standardized. Parate et al., (2011) argued that electrical resistivity measurements can be used to measure soil moisture content for red soils only. Recently, the information on root zone properties are sought by inversion of crop models (Sreelash et al., 2017) by characterizing soil water reservoir and impact of land use and environmental changes on hydrology of agricultural catchments.

Among 24 Critical Zone Observatories around the globe, there is only one observatory on the Kabini River Basin, Karnataka, in India. Considering the huge land area of the country and varied geological and climatic conditions, it is proposed to consider creation of more observatories within country.

\section{Diversified Studies for Management Plans at Watershed and Basin Scale}

\section{Estimation of Water Availability and Budgeting at Different Scales}

The growing demand for groundwater availability and the rapid depletion of resources have opened up a forum to discuss on the extent and spatial distribution of groundwater depletion and the connectivity of aquifer system and its dynamics in terms of geological time span. The water balance of entire India has been studied on daily, monthly and annual time scales (Aggarwal et al., 2013) and it revealed that the VIC model results take into account a large number of parameters influencing the process. Sinha (2015) strongly proposed to design a strategy to understand the geology and geometry of the aquifer system defined by the buried channels in order to get the precise estimation under stress conditions through a 3-Dimensional representation of the paleochannels. Li, Lu et al. (2017) established an understanding of 
the present water budget in Himalayan Basins and proposed a two-way coupled implementation of the Weather Research and Forecasting (WRF) Model. The WRF-Hydro hydrological modeling extension package (WRF/WRF-Hydro) was employed in its offline configuration over a 10 year simulation period for a mountainous river basin in north India to capture precipitation and resulting stream flow hydrograph which shows a good correspondence with observation at monthly timescales. They concluded that WRFHydro modelling system has the potential for predicting potential changes in the atmospherichydrology cycle of ungauged or poorly gauged basins.

\section{Rural, Peri-Urban and Urban Management}

A significant change in Land-Use and Land-Cover is observed through high resolution satellite data. Roy et al. (2015) have generated LULC maps at decadal intervals for 1985, 1995 and 2005 following the International Geosphere Biosphere Program (IGBP) to meet the global standards of interpretation. Various organizations like The Energy Research Institute (TERI), IISc Banglore, SaciWaters, etc have extensively worked at local level along with respective municipal corporations to reduce the usage of freshwater and use of contaminated water after treatment. NGO's have also worked towards the awareness on lake encroachment in order to save them from urbanization. The International Water Management Institute (IWMI) along with IITM undertook a part of international collaborative project to demonstrate the usage of local waste water treatment plants and change in cropping pattern over almost a decade (Jampani et al., 2015).

The lack of technical capacity for the informal construction of small dams in rural India was highlighted by Oblinger et al. (2010). They quantified the seepage loss and thereby came across a strategy to deal with water scarcity. The impact of urbanization on the hydrology of Ganga Basin was studied with quantified observations (Misra, 2011) which revealed the change on water habitats, exports, high concentration of pollution into the rivers, wetlands and reservoirs, destabilize the ecological processes and influence the ecological stability of ecosystems.

It was observed that use of gauge calibrated satellite observations significantly improve the rainfall estimation over the metro cities, in an area with a few rain gauge observations (Mishra 2013). Looking towards another metro city of Kolkata, the impacts of pumping on water sources was reported for planning the future water supply and understanding the threat of contamination (Sahu et al., 2013).

Spatial and temporal trends of mean and extreme rainfall and temperature values for 33 urban centers of Rajasthan helped local stakeholders and water managers to understand the risks related to climate change (Pingale et al., 2014). The rainfall indices over 57 major urban areas were derived for complete century (1901-2010) and future projections were given for next 5 decades from 2010-2060 (Ali et al., 2014).

An experiment was conducted to develop an eco-hydrological model for agricultural practices in rural catchment area, to assess the scope of data collecting strategy in data-scarce region (Jackisch et al., 2014). As a case study of Bangalore city, 26 CMIP5 (Coupled Model Intercomparison Project Version 5) GCMs (General Circulation Model) along with four Representative Concentration Pathway (RCP) scenarios were considered for studying the effects of climate change and to obtain projected IDF relationships. This study helped in quantifying the uncertainties arising from parameters of the distribution fitted to data and the multiple GCM models using Bayesian approach. Markov Chain Monte Carlo (MCMC) method using Metropolis Hastings algorithm is used to obtain posterior distribution of parameters (Rupa et al., 2015). Recently, the high concentration of Black Carbon reported over the high-altitude Himalayan Kashmir Region has posed serious implications for the regional climate, hydrology and cryosphere (Bhat et al., 2017)

\section{Socio-Hydrology}

An emerging theme related to the applications and use of hydrological results in the development of the society is Socio-Hydrology. It was also proposed as "Hydropsychology', where the discussions and transactions between humans and water-related activities should be included in water research (Sivakumar, 2011) and later it was called as "Duty of Water" (Wescoat Jr. et al., 2013). The need got materialized as the scale of interpretation of hydrological conditions, land use and available institutional structures influenced the watershed 
development (Syme et al., 2012) involving interactions between communities for result oriented data collection and dissemination of information. Now the theories of effective communication entertain the importance of hydrological information to users from socio-economic perspective. The challenging tasks of development in mountains could also be tackled by the interventions of stakeholders and interplay of local practices. As a result of socio-hydrological system adoption in Ladakh area, the irrigation and development characteristics took a positive turn in Upper Indus Basin (Nuesser et al., 2012).

Srinivasan, (2015) argued that there are some challenges in incorporating the feedbacks from people and proposed an alternative approach to use the counterfactual trajectories, which will allow policy insights to be gleaned without having to predict social futures. Again, Srinivasan et al. (2015) came out with a multiple-hypothesis approach in the data scarce region of shrinking Arkavathy River. According to them, the approach not only makes a meaningful contribution to the policy debates but also helps prioritizing and designing of future socio-hydrologic research in the watershed. Very recently, Pande and Sivapalan (2017) developed the economic model with various statistics from agriculture, values, norms, technology, economics, trade, environment in space and time, to explain the necessity of socio-hydrology for global water sustainability.

Department of Science and Technology, Government of India (www.dst.gov.in) pronounced the Technology Mission: WAR for Water which says "Winning, Augmentation and Renovation" in 2009. The main objectives of the mission was to find out inexpensive methods of converting saline water into fresh water; to find out methods of harnessing and managing the monsoon rain water; to manage the flood waters; to carry out extensive research on rain water harvesting techniques and for the proper treatment of waste water; and adoption of preventive and protective methods to preserve the wetlands and issues related to them. The agencies involved came up with viable solutions like installation of membrane based devices to provide safe drinking water; use of advanced aerobic, anaerobic process, membrane process and membrane bioreactor to recycle the domestic sewage water etc.; establishing desalination systems; and adopting various methods of recharge (pits, check dams, artificial dugwells etc) for utilising rainwater harvesting techniques.

\section{Trans-Boundary Aquifers (TBA) and global networking}

The study of trans-boundary aquifers on the Kosi River basin (Chen et al., 2013) described the characteristics of water hazards in the basin based on the existing literature and site investigations including hydrology and related aspects. The substantial groundwater depletion over the TBA including Indus River plains (over India and Pakistan) was proposed for the first time as the quantitative assessment of TBAs with an aquifer stress indicator for a period of 1960-2010 (Wada et al., 2013) using groundwater abstraction, groundwater recharge and groundwater contribution to environment flow.

The International Hydrological Programme (IHP) 7 contributed largely to elevate India on global platform through imparting water education for sustainable development, to revise the curriculum development along with Asian countries. IHP 7 collaborated with The Energy and Resource Institute (TERI) to provide wider education for sustainable development support to India and to improve cooperation with non-governmental institutions.

There was a call concerned with water technologies organised by the Directorate-General for Research and Innovation of the European Commission (DG RTD) and the Department of Science and Technology (DST) of India. As an outcome of this call, four EU and four Indian projects were selected for funding namely ECO-INDIA (Energy-Efficient, community based water and wastewater treatment systems for deployment in India), NAWATECH (Natural Water systems and Treatment Technologies), SARASWATI (Supporting consolidation, replication and up-scaling of sustainable waste water treatment and reuse technologies for India) and SWINGS (Safeguarding water resources in India with green and sustainable technologies). This joint collaboration led to the evolving technologies for sustainable water/ wastewater treatment, reuse and recycling with an unprecedented scope for replication and joint business development. Indo-EU project "SaphPani" (www.saphpani.eu) funded by EU for collaborative research including 20 partners from India, Sri Lanka, Europe and Australia. The project aimed towards the 
improvement of natural water treatment systems including River Bank Filtration (RBF), Managed Aquifer Recharge (MAR) and wetlands in India. The project worked on the case studies in various parts of India, particularly water stressed urban and peri-urban areas.

The India-France SARAL/AltiKa mission is the first Ka-band altimetric mission dedicated primarily to oceanography. The mission objectives were firstly the observation of the oceanic mesoscales but also global and regional sea level monitoring, including the coastal zone, data assimilation, and operational oceanography. SARAL/AltiKa also proved to be a great opportunity for inland water applications, for observing ice sheet or icebergs, as well as for geodetic investigations. The mission ended its nominal phase after three years in orbit and began a new phase (drifting orbit) in July 2016 (Verron et al., 2018).

Data sharing is an important aspect of hydrological science studies, be it modelling or prediction. The $\mathrm{H}^{+}$Network (http://hplus.ore.fr/en/) of hydrogeological research sites from India and Europe was established with an aim to maintain and coordinate a network of experimental sites to exchange the data towards a better understanding of

\section{References}

Aggarwal S P, Garg V, Gupta P K, Nikam B R, Thakur P K and Roy P S (2013) Run-off potential assessment over Indian landmass: A macro-scale hydrological modelling approach in Current Science 104 950-959

Ahmed S (2014) A new chapter in groundwater geophysics in India: 3D aquifer mapping through heliborne transient electromagnetic investigations in Journal of the Geological Society of India $\mathbf{8 4} 4$ 501-503

Ali H, Mishra V and Pai D S (2014) Observed and projected urban extreme rainfall events in India in J Geophys Res Atmos 119 621-12, 641, doi: 10.1002/ 2014JD022264

Andrade Rolland (2011) Intervention of Electrical Resistance Tomography (ERT) in Resolving Hydrological Problems of a Semi Arid Granite Terrain of Southern India in Journal of the Geological Society of India 78 337-344

Anoop S, Maurya D K, Rao PV N and Sekhar M (2017) Validation and comparison of LPRM retrieved soil moisture using AMSR2 brightness temperature at two spatial resolutions water cycle and of the aquifer system. It also maintains a research partnership between basic research and professional experience. CSIR-NGRI's Experimental Hydrogeological Park at Chotuppal, Telangana, is one of the research sites in the network. Apart from these, there are many opportunities from DST, India towards collaboration in water science with different countries on the globe.

This review for the period 2001-2018 is showcasing the enormous efforts by Indian researchers in varied fields of surface water and ground water studies. More emphasis is laid to solve the issues related to the coastal hydrology and handling of big datasets acquired by the satellites. This period also witnesses the growth of upcoming areas like palaeoflood hydrology, socio-hydrology, and global networking. The management plans at the watershed as well as basin scale are incorporated in global projects towards sustainable development.

\section{Acknowledgement}

Authors thank the Director, CSIR-NGRI for permission to publish this paper. We greatly appreciate Prof. Harsh K. Gupta for inviting us to write this article.

in the Indian region in IEEE Geoscience and Remote Sensing Letters 4 1561-1564

Arora Tanvi, Boisson A and Ahmed S (2016) Non-intrusive Hydro-geophysical Characterization of the Unsaturated Zone of South India-A case study, in Journal of African Earth Sciences 122 88-97

Aswathy M V, Vijith H and Satheesh R (2008) Factors influencing the sinuosity of Pannagon River, Kottayam, Kerala, India: An assessment using remote sensing and GIS in Environmental Monitoring And Assessment 138 173-180

Baker Victor R (2008) Paleoflood hydrology: Origin, progress, prospects Geomorphology 101 1-13

Ballukaray P N (2001) Hydrogeophysical investigations in Namagiripettai Area, Namakkal District, Tamil Nadu in Journal of the Geological Society of India 58 239-249

Barker (2003) Application of electrical imaging for borehole siting in hardrock regions of India in Journal of the Geological Society of India 61 147-158

Bhat, Mudasir Ahmad, Romshoo S A and Beig Gufran (2017) 
Aerosol black carbon at an urban site-Srinagar, Northwestern Himalaya, India: Seasonality, sources, meteorology and radiative forcing, in Atmospheric Environment 165 336-348

Bollasina Massimo A and Ming Yi (2013) The role of land-surface processes in modulating the Indian monsoon annual cycle in Climate Dynamics 41 2497-2509

Bonell M, Purandara B K, Venkatesh B, Krishnaswamy Jagdish, Acharya H A K, Singh U V, Jayakumar R and Chappell N (2010) The impact of forest use and reforestation on soil hydraulic conductivity in the Western Ghats of India: Implications for surface and sub-surface hydrology in Journal of Hydrology 391 49-64

CGWB report (2014) Concept note on Geogenic contamination of groundwater in India, pp 99

Chatterjee Rana, Jain A K, Chandra S, Tomar V, Parchure P K and Ahmed S (2018) Mapping and management of aquifers suffering from over-exploitation of groundwater resources in Baswa-Bandikui watershed, Rajasthan, India in Environmental Earth Sciences 77157 https://doi.org/ 10.1007/s12665-018-7257-1

Chattopadhyay R, Rao S A, Sabeerali C T, George G, Rao D N, Dhakate A and Salunke K (2015) Large scale teleconnection pattern of Indian summer monsoon as revealed by CFSv2 retrospective seasonal forecast runs Int J Climatol http:// dx.doi.org/10.1002/joc.4556

Chaudhuri A S, Singh P and Rai S C (2017) Assessment of impervious surface growth in urban environment through remote sensing estimates in Environmental Earth Sciences 7615

Chawla Ila and Mujumdar P P (2018) Partitioning uncertainty in streamflow projections under nonstationary model conditions in Advances in Water Resources 112 266-282

Chen J L, Li J, Zhang Z Z and Ni S N (2014) Long-term groundwater variations in Northwest India from satellite gravity measurements inGlobal Planet Change 116 130138

Coyte R M, Jain R C, Srivatava S K, Sharma K C, Khalil A, Ma L and Vengosh A (2018) Large Scale Uranium contamination of groundwater resources in India in Environmental Science and Technology Letters 5341-347, doi: 10.1021/acs.estlett. $8 \mathrm{~b} 00215$

Dar F A, Arora T, Warsi T, Rama Devi A, Md Wajihuddin, Grutzamer G, Bodhankar N and Ahmed S (2017) 3-D hydrogeological model of limestone aquifer for managed aquifer recharge in Raipur of central India in Carbonates and Evaporites 32 459-471
Dar S S and Ghosh P (2017) Estimates of land and sea moisture contributions to the monsoonal rain over Kolkata, deduced based on isotopic analysis of rainwater in Earth System Dynamics 8 313-321

Datta B, Vennalakanti H K and Dhar A (2009) Modeling and control of saltwater intrusion in a coastal aquifer of Andhra Pradesh, India in Journal of Hydro-environment Research 3 148-159

Dhar S and Mazumdar A (2009) Hydrological modelling of the Kangsabati river under changed climate scenario: Case study in India in Hydrological Processes 23 2394-2406

Di Long, Chen X, Scanlon B R, Wada Y, Hong Y, Singh V P, Chen Y, Wang C, Han Z and Yang W (2016) Have GRACE satellites overestimated groundwater depletion in the Northwest India Aquifer? in Scientific Reports 624398

Dixit Y, Hodell David A, Giesche A, Tandon S K, Gazquez F, Saini H S, Skinner L C, Mujtaba S A I, Pawar V, Singh R N and Petrie C A (2018) Intensified summer monsoon and the urbanization of Indus Civilization in northwest India in Scientific Reports $\mathbf{8}$

Ferrant S, Kerr Y, Selles A, Mermoz S, Bouvet A, Le Page M, Al Bitar A, Zribi M, Gascoin S, Maréchal J-C and Durand P (2017) Agro-hydrology from Space (Technical report). 10.13140/RG.2.2.19861.32484

Gardelle J, Berthier E and Arnaud Y (2012) Slight mass gain of Karakoram glaciers in the early twenty-first century Nature Geoscience 5 322-325

Garg K K and Wani S P (2013) Opportunities to Build Groundwater Resilience in the Semi-Arid Tropics in Ground Water 51 679-691

Garg V , Aggarwal S P, Gupta P K, Nikam B R, Thakur P K, Srivastav S K and Kumar A S (2017) Assessment of land use land cover change impact on hydrological regime of a basin in Environmental Earth Sciences 7618

Ghosh S and Dutta S (2012) Impact of climate change on flood characteristics in Brahmaputra basin using a macro-scale distributed hydrological model in Journal of Earth System Science 121 637-657

Ghosh S and Mujumdar P P (2008) Statistical downscaling of GCM simulations to streamflow using relevance vector machine, Advances In Water Resources 31 132-146

Gosain A K, Rao S and Arora A (2011) Climate change impact assessment of water resources of India Current Science 101 356-371

Gowhar Meraj, Shakil Romshoo, A Yousuf, Sadaff Altaf and Farrukh Altaf (2015) Assessing the influence of watershed characteristics on the flood vulnerability of Jhelum basin 
in Kashmir Himalaya Natural Hazards: Journal of the International Society for the Prevention and Mitigation of Natural Hazards 77 153-175

Goyal M K, Ojha C S P and Burn D H (2012) Nonparametric Statistical Downscaling of Temperature, Precipitation, and Evaporation in a Semiarid Region in India, Journal of Hydrologic Engineering 17 615-627

Guiheneuf N, Boisson A, Bour O, Dewandel B, Perrin J, Dausse A, Viossanges M, Chandra S, Ahmed S and Marechal J C (2014) Groundwater flows in weathered crystalline rocks: Impact of piezometric variations and depth-dependent fracture connectivity in Journal of Hydrology 511320 334

Gupta P K, Panigrahy S and Parihar J S (2011) Impact of Climate Change on Runoff of the Major River Basins of India Using Global Circulation Model (HadCM3) Projected Data in Journal of The Indian Society of Remote Sensing 39337 344

Gwala P, Andey Subhash, Nagarnaik P, Ghosh S P, Pal P, Deshmukh P and Labhasetwar P (2014) Design and development of Sustainable Remediation Process for Mitigation of Fluoride Contamination in Ground water and field Application for domestic Use in Science of the Total Environment 488-489 588-94

Haritashya U K, Kumar A and Singh P (2010) Particle size characteristics of suspended sediment transported in meltwater from the Gangotri Glacier, central Himalaya An indicator of subglacial sediment evacuation in Geomorphology 122 140-152

Hengade N and Eldho T I (2016) Assessment of LULC and climate change on the hydrology of Ashti Catchment, India using VIC model in Journal of Earth System Science $\mathbf{1 2 5}$ 1623-1634

Hodlur G K, Dhakate R and Andrade R (2006) Correlation of vertical electrical sounding and borehole-log data for delineation of saltwater and freshwater aquifers in Geophysics 71 G11-G20

Immerzeel W W, Wanders N, Lutz A F, Shea J M and Bierkens M F P (2015) Reconciling high-altitude precipitation in the upper Indus basin with glacier mass balances and runoff in Hydrology and earth system sciences 19 4673-4687, doi: 10.5194/hess-19-4673-2015

Islam A, Sikka A K, Saha B and Singh A (2012) Streamflow Response to Climate Change in the Brahmani River Basin, India in Water Resources Management 26 1409-1424

Jackisch C, Zehe E, Samaniego L and Singh A K (2014) An experiment to gauge an ungauged catchment: rapid data assessment and eco-hydrological modelling in a data-scarce rural catchment in Hydrological Sciences Journal-Journal Des Sciences Hydrologiques 59 2103-2125

Jain S K and Kumar P (2014) Environmental flows in India: Towards sustainable water management in Hydrological Sciences Journal-Journal Des Sciences Hydrologiques 59 751-769

Jampani M, Amerasinghe P and Pavelic P (2015) An integrated approach to assess the dynamics of a peri-urban watershed influenced by wastewater irrigation Journal of Hydrology 523 427-440

Jeelani Gh, Bhat N A and Shivanna K (2010) Use of delta O-18 tracer to identify stream and spring origins of a mountainous catchment: A case study from Liddar watershed, Western Himalaya, India in Journal of Hydrology 393 257-264

Jeelani Gh, Kumar U S and Kumar B (2013) Variation of delta O18 and delta $\mathrm{D}$ in precipitation and stream waters across the Kashmir Himalaya (India) to distinguish and estimate the seasonal sources of stream flow Journal of Hydrology 481 157-165

Jeuland M, Harshadeep N, Escurra J, Blackmore D and Sadoff C (2013) Implications of climate change for water resources development in the Ganges basin in Water Policy 15 26-50

Kale V S (2008) Palaeoflood hydrology in the Indian context Journal of the geological society of India 71 56-66

Kanagaraj G, Elango L, Sridhar S G D and G Gowrisankar (2018) Hydrogeochemical processes and influence of seawater intrusion in coastal aquifers south of Chennai, Tamil Nadu, India Environ Sci Pollut Res 25 8989-9011. https://doi.org/ 10.1007/s11356-017-0910-5

Kumar R, Singh R D and Sharma K D (2005) Water resources of India Current Science $\mathbf{8 9}$

Kumar Sat, Sekhar M and Bandyopadhyay S (2009) Assimilation of remote sensing and hydrological data using adaptive filtering techniques for watershed modelling (1196) in Current Science 97

Kuriakose Sekhar L, Jetten V G, van Westen C J, Sankar G and van Beek L P H (2008) Pore water pressure as a trigger of shallow landslides in the western ghats of kerala, india: some preliminary observations from an experimental catchment, Physical Geography 29 374-386

Li Lu, Gochis David J, Sobolowski Stefan and Mesquita Michel D S (2017) Evaluating the present annual water budget of a Himalayan headwater river basin using a high-resolution atmosphere-hydrology model Journal of Geophysical Research-Atmospheres 122 4786-4807

Massuel S, George B A and Venot J-P, Bharati L and Acharya S 
(2013) Improving assessment of groundwater-resource sustainability with deterministic modelling: A case study of the semi-arid Musi sub-basin South India Hydrogeology Journal 21 1567-1580

Matern K, Weigand H, Singh A and Mansfeldt T (2017) Environmental status of groundwater affected by chromite ore processing residue (COPR) dumpsites during premonsoon and monsoon seasons Environmental Science And Pollution Research 24 3582-3592

Meenu R, Rehan, S and Mujumdar P P (2013) Assessment of hydrologic impacts of climate change in Tunga-Bhadra river basin, India with HEC-HMS and SDSM, Hydrological Processes 27 1572-1589

Menon A, Levermann A, Schewe J, Lehmann J and Frieler K (2013) Consistent increase in Indian monsoon rainfall and its variability across CMIP-5 models Earth System Dynamics 4 287-300

Michael Holly A and Voss Clifford I (2008) Evaluation of the sustainability of deep groundwater as an arsenic-safe resource in the Bengal Basin Proceedings of The National Academy of Sciences of The United States of America 105 8531-8536

Mishra A K (2013) Effect of rain gauge density over the accuracy of rainfall: A case study over Bangalore, India Springerplus 2

Misra A K (2011) Impact of Urbanization on the Hydrology of Ganga Basin (India), Water Resources Management 25 705-719

Mondal N C, Das S N and Singh V S (2008) Integrated approach for identification of potential groundwater zones in Seethanagaram Mandal of Vizianagaram District, Andhra Pradesh, India Journal of Earth System Science Open Access 117 133-144

Mujumdar P P (2008) Implications of climate change for sustainable water resources management in India Physics and Chemistry of The Earth 33 354-358

Mujumdar P P and Ghosh S (2008) Modeling GCM and scenario uncertainty using a possibilistic approach: Application to the Mahanadi River, India Water Resources Research 44, W06407

Mukherjee S (2008) Role of satellite sensors in groundwater exploration Sensors Open Access 8 2006-2016

Mukhopadhyay B, (2013) Signature and hydrologic consequences of climate change within the upper-middle Brahmaputra Basin Hydrological Processes 27 2126-2143

Munz Philipp M, Lueckge A, Siccha M, Boell A, Forke S, Kucera $M$ and Schulz H (2017) The Indian winter monsoon and its response to external forcing over the last two and a half centuries Climate Dynamics 49 1801-1812

Murray S J (2013) Present and future water resources in India: Insights from satellite remote sensing and a dynamic global vegetation model Journal of Earth System Science 122 113

Narula K K and Gosain A K (2013) Modeling hydrology, groundwater recharge and non-point nitrate loadings in the Himalayan Upper Yamuna basin Science of The Total Environment 468 S102-S116

Nayak P C and Sudheer K P (2008) Fuzzy model identification based on cluster estimation for reservoir inflow forecasting Hydrological Processes 22 827-841

Nuesser M, Schmidt S and Dame J (2012) Irrigation and Development in the Upper Indus Basin Characteristics and Recent Changes of a Socio-hydrological System in Central Ladakh, India Mountain Research And Development 32 51-61

Oblinger J A, Moysey Stephen M J, Ravindrinath R and Guha C (2010) A pragmatic method for estimating seepage losses for small reservoirs with application in rural India Journal of Hydrology 385 230-237

Opportunities in WIREs Water, 4 e1193. doi: 10.1002/wat2.1193

Pai D S, Sreejith O P, Nargund S G, Musale Madhuri and Tyagi Ajit (2011) Present operational long range forecasting system for southwest monsoon rainfall over India and its performance during 2010 Mausam 62 179-196

Pande S and Sivapalan M (2017) Overview Progress in sociohydrology: a meta-analysis of challenges and

Pandithurai G, Seethala C, Murthy B S and Devara P C S (2008) Investigation of atmospheric boundary layer characteristics for different aerosol absorptions: Case studies using CAPS model Atmospheric Environment 42 4755-4768

Panwar S and Chakrapani G J (2013) Climate change and its influence on groundwater resources Current Science 105 $37-46$

Parate H R, Kumar M S, Mohan, Descloitres M, Barbiero L, Ruiz L, Braun Jean-Jacques, Sekhar M and Kumar C (2011) Comparison of electrical resistivity by geophysical method and neutron probe logging for soil moisture monitoring in a forested watershed, Current Science $\mathbf{1 0 0}$ 1405-1412

Patil M N, Waghmare R T, Halder S and Dharmaraj T(2011) Performance of Noah land surface model over the tropical semi-arid conditions in western India Atmospheric Research 99 85-96

Pattanaik DR and Kumar A (2010) Prediction of summer monsoon 
rainfall over India using the NCEP climate forecast system Clim Dyn 34 557-572

Pechlivanidis I G and Arheimer, B (2015) Large-scale hydrological modelling by using modified PUB recommendations: the India-HYPE case, Hydrology and Earth System Sciences 19 4559-4579

Pingale S M, Khare D, Jat M K and Adamowski J (2014) Spatial and temporal trends of mean and extreme rainfall and temperature for the 33 urban centers of the arid and semiarid state of Rajasthan, India Atmospheric Research 138 73-90

Pottakkal Jose George, Ramanathan A, Singh V B, Sharma P, Azam Mohd. Farooq and Linda A (2014) Characterization of subglacial pathways draining two tributary meltwater streams through the lower ablation zone of Gangotri glacier system, Garhwal Himalaya, India, Current Science 107 613-621

Pratibha S and Kulkarni Anil V (2018) Decadal change in supraglacial debris cover in Baspa basin, Western Himalaya Current Science 114 792-799

Qazi Nuzhat Q, Bruijnzeel L, Adrian, Rai S P and Ghimire C P (2017) Impact of forest degradation on streamflow regime and runoff response to rainfall in the Garhwal Himalaya, Northwest India, Hydrological Sciences Journal-Journal Des Sciences Hydrologiques 62 1114-1130

Rai B, Tiwari A and Dubey V S (2005) Identification of groundwater prospective zones by using remote sensing and geoelectrical methods in Jharia and Raniganj coalfields, Dhanbad district, Jharkhand state Journal of Earth System Science 114 515-522

Raje D, Priya P and Krishnan R (2014) Macroscale hydrological modelling approach for study of large scale hydrologic impacts under climate change in Indian river basins, Hydrological Processes 28 1874-1889

Rajeevan M, Pai D S, Kumar R A and Lal B (2007) New statistical models for long rangeforecasting of southwest monsoon rainfall over India Clim Dyn http://dx.doi.org/10.1007/ s00382-006-019706

Ramsankaran R A A J, Kothyari U C, Ghosh S K, Malcherek A and Murugesan Krishnan (2013) Physically-based distributed soil erosion and sediment yield model (DREAM) for simulating individual storm events Hydrological Sciences Journal-Journal Des Sciences Hydrologiques 58 872-891

Ramu A D, Sabeerali C T, Chattopadhyay R, Rao D, Nagarjuna, George Gibies, Dhakate A R, Salunke K, Srivastava A, and Rao Suryachandra A (2016) Indian summer monsoon rainfall simulation and prediction skill in the CFSv2 coupled model: impact of atmospheric horizontal resolution J Geophys Res Atmos 121 http://dx.doi.org/10.1002/ 2015JD024629

Ranade A, Mitra A K, Singh N and Basu S (2014) A verification of spatio-temporal monsoon rainfall variability across Indian region using NWP model output, Meteorology And Atmospheric Physics 125 43-61

Ravikumar P and Somashekar R K (2011) Environmental Tritium (H-3) and hydrochemical investigations to evaluate groundwater in Varahi and Markandeya river basins, Karnataka, India, Journal Of Environmental Radioactivity $1022153-162$

Reddy D V, Nagabhushanam P and Sukhija B S (2011) Earthquake (M 5.1) induced hydrogeochemical and delta O-18 changes: validation of aquifer breaching-mixing model in Koyna, India Geophysical Journal International 1841 359-370

Reddy V Ratna (2012) Hydrological externalities and livelihoods impacts: Informed communities for better resource management, Journal Of Hydrology 412 279-290

Rehana S and Mujumdar P P (2012) Climate change induced risk in water quality control problems Journal of Hydrology 44 63-77

Rehana S and Mujumdar P P (2013) Regional impacts of climate change on irrigation water demands Hydrological Processes 27 2918-2933

Renganayaki Parimala S and Elango L (2013) Impact of recharge from a check dam on groundwater quality and assessment of suitability for drinking and irrigation purposes, Arabian Journal of Geosciences DOI 10.1007/s12517-013-0989-z

Roy N G and Sinha R (2007) Understanding confluence dynamics in the alluvial Ganga-Ramganga valley, India: An integrated approach using geomorphology and hydrology, Geomorphology 92 182-197

Roy N G and Sinha R (2014) Effective discharge for suspended sediment transport of the Ganga River and its geomorphic implication Geomorphology 227 18-30

Roy N G and Sinha R (2017) Linking hydrology and sediment dynamics of large alluvial rivers to landscape diversity in the Ganga dispersal system, India, in Earth Surface Processes And Landforms 42 1078-1091

Roy P D, Nagar Y C, Juyal N, Smykatz-Kloss W and Singhvi A K (2009) Geochemical signatures of Late Holocene paleohydrological changes from Phulera and Pokharan saline playas near the eastern and western marginsvof the Thar Desert, India Journal of Asian Earth Sciences 34 275-286

Roy P K and Mazumdar A (2007) Study on hydrology and drought in the flood region of Damodar River Basin Journal of The Geological Society of India 69 1011-1019 
Rupa Chandra, Ujjwal Saha and Mujumdar P P (2015) Model and parameter uncertainty in IDF relationships under climate change Advances in Water Resources 79 127-139

Saha D, Sinha U K and Dwivedi S N (2011) Characterization of recharge processes in shallow and deeper aquifers using isotopic signatures and geochemical behavior of groundwater in an arsenic-enriched part of the Ganga Plain in Applied Geochemistry 26 432-443

Sahu P, Michael Holly A, Voss Clifford I and Sikdar P K (2013) Impacts on groundwater recharge areas of megacity pumping: analysis of potential contamination of Kolkata, India, water supply Hydrological Sciences Journal-Journal Des Sciences Hydrologiques 58 1340-1360

Salvi K and Ghosh S (2013) High-resolution multisite daily rainfall projections in India with statistical downscaling for climate change impacts assessment Journal of Geophysical Research: Atmospheres 118 3557-3578

Samadder Ratan K, Kumar S and Gupta R P (2011) Paleochannels and their potential for artificial groundwater recharge in the western Ganga plains, Journal of Hydrology 400 154164

Samala B K and Krishnan R (2008) Cloud-radiative impacts on the tropical Indian Ocean associated with the evolution of 'monsoon breaks' International Journal of Climatology 28 205-217

Saxena V K, Singh V S, Mondal N C and Jain S C (2003). Use of chemical parameters to delineation fresh groundwater resources in Potharlanka Island, India Environ Geol 44 516-521

Saxena V K, Mondal N C and Singh V S (2004) Identiûcation of seawater ingress using $\mathrm{Sr}$ and B in Krishna delta Curr Sci 86 586-590

Scanlon B R, Zhang Z, Save H, Sun A Y, Mueller S, Hannes van B L P H, Wiese David N, Wada Y, Long Di, Reedy R C, Longuevergne L, Doll P and Bierkens Marc F P (2018) Global models underestimate large decadal declining and rising water storage trends relative to GRACE satellite data in Proceedings of The National Academy of Sciences of The United States Of America 115 E1080-E1089

Sen Roy, Shouraseni, Mahmood Rezaul, Niyogi Dev, Lei Ming, Foster, Stuart A, Hubbard, Kenneth G, Douglas, Ellen and Pielke Sr, Roger (2007) Impacts of the agricultural Green Revolution - induced land use changes on air temperatures in India Journal of Geophysical Research-Atmospheres 112 D21

Shah Reepal, Sahai A K and Mishra V (2017) Short to subseasonal hydrologic forecast to manage water and agricultural resources in India Hydrol Earth Syst Sci 21
707-720 doi: 10.5194/hess-21-707-2017

Sharma A, Kumar K, Laskar A, Singh S K and Mehta P (2017) Oxygen, deuterium, and strontium isotope characteristics of the Indus River water system, Geomorphology 2845 16

Sharma S P and Baranwal V C (2005) Delineation of groundwaterbearing fracture zones in a hard rock area integrating very low frequency electromagnetic and resistivity data Journal of Applied Geophysics 57 155-166

Sharma S, Shukla A D, Bartarya S K, Marh B S and Juyal Navin (2017) The Holocene floods and their affinity to climatic variability in the western Himalaya, India, Geomorphology 290 317-334

Siderius, C., Biemans H., Wiltshire A., Rao S., Franssen W. H. P., Kumar P., Gosain A. K., van Vliet M T H and Collins D N (2013) Snowmelt contributions to discharge of the Ganges

Sikdar P K and Sahu P (2009) Understanding wetland sub-surface hydrology using geologic and isotopic signatures Hydrological Earth System Science 13 1313-1323

Singh A K, Jasrotia A S, Taloor A K, Kotlia B S, Kumar V, Roy S, Ray Prashant K C, Singh K K, Singh A K and Sharma Arun Kumar (2017) Estimation of quantitative measures of total water storage variation from GRACE and GLDAS-NOAH satellites using geospatial technology Quaternary International 444 191-200

Singh C R, Thompson J R, French J R, Kingston D G and Mackay A W (2010) Modelling the impact of prescribed global warming on runoff from headwater catchments of the Irrawaddy River and their implications for the water level regime of Loktak Lake, northeast India Hydrology And Earth System Sciences 14 1745-1765

Singh M, Singh I B and Mueller G (2007) Sediment characteristics and transportation dynamics of the Ganga River Geomorphology 86 144-175

Singh P K, Bhunya P K, Mishra S K and Chaube U C (2008) A sediment graph model based on SCS-CN method Journal of Hydrology 349 244-255

Singh R P and Gupta P K (2016) Developments in Remote Sensing Techniques for Hydrological Studies in Proc Indian Natn Sci Acad 82 773-786, doi: 10.16943/ptinsa/2016/48484

Singh R P and Gupta P K (2017) Development in remote sensing techniques for hydrological studies Proc Indian Natl Sci Acad 82 773-786

Singh S and Mishra A (2012) Spatiotemporal analysis of the effects of forest covers on water yield in the Western Ghats of peninsular India Journal of Hydrology 446 24-34 
Singh V S, Jain S C, Rao T V, Rao M N and Negi B C (2003) Groundwater targeting in a shalley limestone terrain: An integrated approach in Journal of the Geological Society of India 62 769-772

Sinha R and Densmore A L (2016) Water governance in India: Focus on sustainable groundwater management in Economic and Political Weekly 51 (52)

Sinha R, Bapalu GV, Singh L K and Rath B (2008) Flood Risk Analysis in the Kosi River Basin, North Bihar using MultiParametric Approach of Analytical Hierarchy Process (AHP) Photonirvachak-Journal of The Indian Society of Remote Sensing 36 335-349

Sivakumar Bellie (2011) Hydropsychology: the human side of water research, Hydrological Sciences Journal-Journal Des Sciences Hydrologiques 56 719-732

Sreedevi P D, Sreekanth P D, Khan H H and Ahmed S (2013) Drainage morphometry and its influence on hydrology in an semi arid region: using SRTM data and GIS Environmental Earth Sciences 70 839-848

Sreelash K, Buis S, Sekhar M, Ruiz L, Tomer S K and Guerif Martine (2017) Estimation of available water capacity components of two-layered soils using crop model inversion: Effect of crop type and water regime, Journal of Hydrology 546 166-178

Sridhar A (2007) Mid-late holocene hydrological changes in the Mahi river, arid western India in Geomorphology88 (3-4) 285-297

Sridhar A (2009) Evidence of a late-medieval mega flood event in the upper reaches of the Mahi River basin, Gujarat Current Science 96 1517-1520

Srinivasan V (2015) Reimagining the past - Use of counterfactual trajectories in socio-hydrological modelling: the case of Chennai, India in Hydrology And Earth System Sciences 192

Srinivasan V, Thompson S, Madhyastha K, Penny G, Jeremiah K and Lele $S$ (2015) Why is the Arkavathy River drying? A multiple-hypothesis approach in a data-scarce region, Hydrology And Earth System Sciences 19 1905-1917

Srivastava D, Kumar A, Verma A and Swaroop S (2014) Analysis of Climate and Melt-runoff in Dunagiri Glacier of Garhwal Himalaya (India) Water Resources Management 283035 3055

Subbarao N, Chakradhar G K J and Srinivas V (2001) Identification of groundwater potential zones using remote sensing techniques in and around Guntur Town, Andhra Pradesh, India , Journal of the Indian Society of Remote Sensing 29 $69-78$
Sundararajan N, Srinivas Y, Chary M N, Nandakumar G and Chary A H (2004) Delineation of structures favourable to groundwater occurrence employing seismic refraction method - A case study from Tiruvuru, Krishna district, Andhra Pradesh Proceedings of the Indian Academy of Sciences, Earth and Planetary Sciences, Open Access 113 $3259-267$

Surinaidu L, Bacon C G D and Pavelic P (2013) Agricultural groundwater management in the Upper Bhima Basin, India: current status and future scenarios Hydrology And Earth System Sciences 17 507-517

Syme Geoffrey J, Reddy V. R, Pavelic P, Croke B and Ranjan Ram (2012) Confronting scale in watershed development in India in Hydrogeology Journal20 (5) 985-993

Thayyen Renoj J, Gergan, J T and Dobhal D P (2007) Role of glaciers and snow cover on headwater river hydrology in monsoon regime - Micro-scale study of Din Gad catchment, Garhwal Himalaya, India, Current Science 92 376-382

Tiwari S, Kar Sarat C and Bhatla R (2018) Mid-21st century projections of hydroclimate in Western Himalayas and Satluj River basin, Global And Planetary Change 161 1027

Tiwari VM, Wahr J and Swenson S (2009) Dwindling groundwater resources in northern India, from satellite gravity observations in Geophyscial Research Letters 36 L18401, doi:10.1029/2009GL039401

Uniyal B, Jha M K and Verma A K (2015a) Assessing Climate Change Impact on Water Balance Components of a River Basin Using SWAT Model Water Resources Management 29 4767-4785

Uniyal B, Jha M K and Verma A K (2015b) Parameter identification and uncertainty analysis for simulating streamflow in a river basin of Eastern India Hydrological Processes 29 3744-3766

Venkatesh B, Lakshman N, Purandara B K and Reddy V B (2011) Analysis of observed soil moisture patterns under different land covers in Western Ghats, India in Journal of Hydrology 397 281-294

Verron Jacques, Bonnefond Pascal, Aouf Lofti, Birol Florence, Bhowmick Suchandra A, Calmant Stephane, Conchy Taina, Cretaux Jean-Francois, Dibarboure Gerald, Dubey A K, Faugere Yannice, Guerreiro Kevin, Gupta P K, Hamon Mathieu, Jebri Fatma, Kumar Raj, Morrow Rosemary, Pascual, Ananda, Pujol Marie-Isabelle, Remy, Elisabeth, Remy Frederique, Smith, Walter H F, Tournadre J and Vergara O (2018) The Benefits of the Ka-Band as Evidenced from the SARAL/AltiKa Altimetric Mission: Scientific Applications, Remote Sensing 102 
Wada Y and Heinrich L (2013) Assessment of transboundary aquifers of the world-vulnerability arising from human water use in Environmental Research Letters 82

Wescoat Jr J L (2013) Reconstructing the duty of water: a study of emergent norms in socio-hydrology, Hydrology And Earth System Sciences 17 4759-4768

Wilk J and Hughes D A (2002) Simulating the impacts of land-use and climate change on water resource availability for a large south Indian catchment Hydrological Sciences
Journal 47 https://doi.org/10.1080/02626660209492904

www.eco-india.org

www.nawatech.net

Www.swingsproject.com

Yadav G S and Singh S K (2007) Integrated resistivity surveys for delineation of fractures for ground water exploration in hard rock areas in Journal of Applied Geophysics 62 301312. 